ISSN 0103-5150

Fisioter. Mov., Curitiba, v. 29, n. 3, p. 609-622, Jul./Set. 2016

Licenciado sob uma Licença Creative Commons

DOI: http://dx.doi.org.10.1590/1980-5918.029.003.A019

(c)

\title{
The Pilates method in the rehabilitation of musculoskeletal disorders: a systematic review
}

\author{
O método Pilates na reabilitação de distúrbios \\ musculoesqueléticos: uma revisão sistemática
}

\author{
Josiane Cristiane Cruz $^{[a, b]}$, Rafaela Liberali ${ }^{[c]}$, Ticiane Marcondes Fonseca da Cruz ${ }^{[\mathrm{d}]}$, \\ Maria Ines Artaxo Netto ${ }^{[\mathrm{d}]^{*}}$ \\ [a] Universidade Gama Filho (UGF), Rio de Janeiro, RJ, Brazil \\ [b] Universidade Federal dos Vales do Jequitinhonha e Mucuri (UFVJM), Diamantina, MG, Brazil \\ [c] Universidade Estácio de Sá, Florianópolis, SC, Brazil \\ [d] Universidade Estácio de Sá, São Paulo, SP, Brazil
}

\section{Abstract}

Introduction: Joseph Pilates created an authentic method of physical and mental conditioning, which he called Contrology and defined as the complete coordination of body, mind and spirit. Recent studies indicate that the Pilates Method is a useful tool in rehabilitation can improve overall health, sports performance and help in the prevention and attenuation of injuries and disorders of the musculoskeletal system. Musculoskeletal disorders are prevalent and costly conditions that develop gradually, presenting a chronic course and often remain untreated. Objective: This study aimed to identify the effects of the Pilates Method in the rehabilitation of musculoskeletal disorders through a systematic review. Methods: An active search was performed in the PubMed, PEDro, Scielo and Bireme databases. A total of 24 studies were pre-selected and their methodological quality was evaluated based on the PEDro scale. Of these, 14 fulfilled the selection criteria. Results: The studies analyzed indicate that Pilates can be effective both for the treatment of

*JCC: BS, e-mail: josiczfisio@gmail.com

RL: MS, e-mail: rafaelametodologia@gmail.com

TMFC: MS, e-mail: ticianecruz@gmail.com

MIAN: BS, e-mail: inesartaxo@gmail.com 
conditions such as scoliosis, back pain, ankylosing spondylitis and breast cancer, and for preventing injuries in adults, elderly people and athletes. Conclusion: The high methodological variability requires that these studies be viewed with caution. It indicates the need for the performance of new studies with high methodological quality and standardization of evaluation instruments.

Keywords: Pilates Method. Musculoskeletal Diseases. Rehabilitation.

\section{Resumo}

Introdução: Joseph Pilates criou um método autêntico de condicionamento físico e mental, que chamou de Contrologia e o definiu como a completa coordenação de corpo, mente e espírito. Estudos recentes indicam que o Método Pilates é uma ferramenta útil na reabilitação, podendo melhorar a saúde geral, o desempenho esportivo, além de ajudar na prevenção e atenuação de lesões e disfunções do sistema musculoesquelético. As disfunções musculoesqueléticas são condições prevalentes e onerosas, que se desenvolvem gradualmente, apresentando um curso crônico e muitas vezes permanecem sem tratamento. Objetivo: Este estudo tem como objetivo identificar os efeitos do Método Pilates na reabilitação de distúrbios musculoesqueléticos através de uma revisão sistemática. Métodos: A busca ativa foi realizada nas bases de dados: PubMed, PEDro, Scielo e Bireme. Foram pré-selecionados 24 estudos, que tiveram sua qualidade metodológica avaliada com base na escala PEDro. Destes, 14 se adequaram aos critérios de seleção. Resultados: Os estudos analisados indicam que o Pilates pode ser eficaz tanto para o tratamento de afecções como escoliose, lombalgia, espondilite anquilosante e câncer de mama, quanto para a prevenção de lesões em adultos, idosos e atletas. Conclusão: A alta variabilidade metodológica exige que esses estudos sejam vistos com cautela. E indica a necessidade de realização de novos estudos com alta qualidade metodológica e padronização dos instrumentos de avaliação.

Palavras-chave: Método Pilates. Doenças Musculoesqueléticas. Reabilitação.

\section{Introduction}

Joseph Hubertus Pilates was born in 1880, near Düsseldorf in Germany (1). During childhood, he suffered a multitude of illnesses resulting in muscular weakness. Determined to overcome his weakness, he dedicated his life to become more physically strong (2). During the First World War, while he was interned, his experiences allowed him to develop an authentic method of physical and mental conditioning, which he perfected over the subsequent 50 years, until his death in 1967 (3).

Joseph H Pilates called his method Contrology and defined it as the complete coordination of body, mind and spirit. Contrology was created in order to develop the body uniformly, restore physical vitality, correct wrong postures, invigorate the mind and elevate the spirit (4). Recent studies indicate that Pilates is a useful tool in rehabilitation $(5,6,7)$ and can improve overall health, sports performance, proprioception, the level of pain (8), flexibility (9), the degree of depression, strength and muscular endurance (10), encourage the control of the mobility of the trunk and pelvic segments, as well as help in prevention and mitigation of injuries and dysfunctions of the musculoskeletal system (11).

Musculoskeletal disorders are prevalent and costly conditions for primary healthcare (12). They develop gradually, presenting a chronic course, and often go untreated. Although many symptoms are associated, the most notable is pain, which can worsen gradually and progress to incapacity (13). Repetitive movements and inadequate long-term posture alter the characteristics of the muscle tissue and can cause muscle dysfunction, altered movement pattern, pain and movement disorders (14). To change this condition, strength training can prevent disuse atrophy and additional deconditioning, as well as improve muscle and cardiorespiratory function in people with muscular disease (15).

Advanced musculoskeletal fitness is directly associated with functional independence, mobility, 
glucose homeostasis, bone health, psychological well-being and overall quality of life and is inversely associated with the risk of falls, disease and premature death. This evidence provides direct support for the recent recommendation for resistance training and flexibility exercises, carried out at least twice a week, to maintain functional status, promote physical activity throughout life and improve the overall quality of life (16). It is also important to mention that a lack of coordination in the core muscles can lead to a loss of movement efficiency and compensatory patterns, causing stress and overuse injuries. Thus, the motor relearning of inhibited muscles may be more important than strength in patients with musculoskeletal injuries (17). In this context, the Pilates method appears to be an interesting alternative for the treatment of musculoskeletal disorders, and for the maintenance of health and quality of life.

The aim of this study was to investigate, through a systematic review, the Pilates method in the rehabilitation of musculoskeletal disorders.

\section{Methods}

A systematic review was used as the methodology, which identifies, selects and critically evaluates studies considered relevant, to give theoretical and practical support for the classification and analysis of the bibliographic study (18).

A review of articles was performed with national [07] and international studies [17] and dissertations [03], for the years 2003 to 2012. The databases searched were: U.S. National Library of Medicine
(PubMed), Physiotherapy Evidence Database (PEDro), Scientific Electronic Library Online (SciELO) and Virtual Health Library (BIREME). The descriptors used in the search for the articles were: Pilates, musculoskeletal disorders, lumbar spine, cervical spine, chronic pain, rehabilitation, and occupational diseases.

After detailed reading of the studies $(n=24)$ selected, those that had no protocols (volume and intensity) reported in the article ( $\mathrm{n}=0)$, evaluated only qualitative measures $(n=1)$, were literature reviews $(\mathrm{n}=1)$ or quasi-experimental studies $(\mathrm{n}=1)$, had low methodological quality $(n=2)$ or did not have a control group compared to the Pilates $(n=4)$ were excluded. The methodological quality of studies was assessed based on the PEDro scale (19) (Table 1). The inclusion criteria of the articles were: randomized clinical trials that evaluated the efficacy of the Pilates method for prevention or treatment of musculoskeletal disorders, that obtained a score greater than 3 on the PEDro scale and that were published in journals with rating greater than or equal to B1 in the webqualis of CAPES.

The studies potentially appropriate for inclusion in the review $(n=14)$ consisted of 1 doctoral dissertation of the University of Miami and 13 articles found in the following journals: Motriz [1]; Revista Brasileira de Medicina do Esporte [1]; Archives of Physical Medicine and Rehabilitation [1]; Rheumatology International [1]; Journal of Strength and Conditioning Research [1]; Journal of Bodywork \& Movement Therapies [2]; European Journal of Physical and Rehabilitation Medicine [1]; Journal of Orthopaedic \& Sports Physical Therapy [1]; Asian Journal of Sports Medicine [1]; Clinical Biomechanics [1]; Journal of Sport Rehabilitation [1]; and BMC Geriatrics [1].

Table 1 - PEDro scale of Methodological Classification

(To be continued)

\begin{tabular}{|c|c|c|}
\hline Criterion & Present & Score \\
\hline Specification of the Inclusion Criteria & Yes/No & - \\
\hline Random Allocation of the Subjects into groups & Yes/No & $1 / 0$ \\
\hline Allocation of the Subjects was concealed & Yes/No & $1 / 0$ \\
\hline Similar groups in relation to prognostic indicators & Yes/No & $1 / 0$ \\
\hline Blinding of the subjects & Yes/No & $1 / 0$ \\
\hline Blinding of the professionals who administered the therapy & Yes/No & $1 / 0$ \\
\hline Blinding of the evaluators & Yes/No & $1 / 0$ \\
\hline Measurement of at least one key outcome in $85 \%$ of the initial subjects & Yes/No & $1 / 0$ \\
\hline $\begin{array}{l}\text { All subjects received treatment or control condition as allocated, otherwise, the data for at } \\
\text { least one key outcome was analyzed by "intention to treat" }\end{array}$ & Yes/No & $1 / 0$ \\
\hline
\end{tabular}


Table 1 - PEDro scale of Methodological Classification

(Conclusion)

\begin{tabular}{l|cc}
\hline Criterion & Present & \multicolumn{2}{c}{ Score } \\
\hline Reporting of between-groups statistical comparisons of at least one key outcome & Yes/No & $1 / 0$ \\
\hline Presentation both point measures and measures of variability for at least one key outcome & Yes/No & $1 / 0$ \\
\hline & Total & Total score/10 \\
\hline
\end{tabular}

Note: $\mathrm{BD}=$ Bone densitometry. $\mathrm{HAP}=$ Human Activity Profile questionnaire.

\section{Results}

The results of studies investigating the Pilates method in the rehabilitation of musculoskeletal disorders are described below and summarized in Table 2a;2b;2c;2d;2e;2f.

All the studies analyzed in table 1 were classiied as randomized and controlled. The 14 studies included the following populations and samples: 31 university students of $22 \pm 2$ years of age (20); 11 athletes aged between 17 and 20 years, mean $18.1 \pm$ 0.83 anos (21); 27 elderly people living in the community, aged $67.3 \pm 6.5$ years (22); 55 volunteers aged between 28 and 69 years, mean $45.23 \pm 10.73$ 23); 44 volunteers aged between 25 and 65 years (9); 52 elderly people between 60 and 78 years of age (mean $66 \pm 4$ years) (24); 21 volunteers aged between 25 and 62 years (25); 60 patients with breast ncer aged between 18 and 75 years (26); 39 physically active adults with a mean age of $34 \pm 8$ years for the control group and $37 \pm 9$ years for the exercise group (27); 40 healthy men and women with a mean age of $31.65 \pm 6.21$ years (11); 10 healthy subjects with a mean age of $33.1 \pm 8.6$ years in the Pilates group and 9 healthy individuals with a mean age of $28.6 \pm 3.7$ years in the Control group (28); 34 healthy adults equally divided into two groups, with a mean age of $27.3 \pm 4$ years in the control group and $27.5 \pm 3.6$ years of age in the Pilates group (29); 34 patients with chronic lower back pain and a mean age of $40.6 \pm 9.7$ years (8); 39 recently hospitalized, elderly patients (30). In the study of Gladwell et al. (8), there were significant differences between the Pilates and Control groups in terms of age, however, not for the initial measures.

The aims of the studies of Table 1, were to evaluate the efficacy of the Pilates Method regarding pain $(20,23,25,27,8)$, flexibilidade $(21,9,26,11)$, strength $(22,28)$, balance $(22,9,24,29)$, functionality $(22,23,24,25,27,8)$, quality of life $(23,24$, 26), muscular resistance (9), posture (9), fatigue (26), lumbo-pelvic stability (11), to quantify the effects of a Pilates program in the biomechanics of the shoulder and trunk (28), and to measure the participation and adherence to Pilates exercises (30).

Of the 14 studies analyzed, 4 evaluated pain, 5 evaluated flexibility, 3 strength, 4 balance, 6 functionality, 3 quality of life, 1 posture, 1 fatigue, 1 lumbo-pelvic stability, 1 the biomechanics of shoulder and trunk and 1 evaluated participation and adherence. The following instruments were used to evaluate pain: Borg CR10 scale (20), Bath Ankylosing Spondylitis Disease Activity Index (BASDAI) (23), Oswestry Low Back Pain Disability Questionnaire (25), pain sub-scale of the Miami Back Index (25), pain sub-scale of the SF-36 (25) Numerical Rating Scale of 101 points (NRS-101) (27), and Roland Morris pain rating visual-analog scale (8). Flexibility was evaluated through: flexibility test on the Wells bench $(21,9,11)$, fleximeter $(21)$, supine hamstring flexion test (9), and modified sit and reach test (26). Muscular strength of knee extensors was measured in a sitting position with hips and knees at $90^{\circ}$ through the maximum extension effort against an elastic resistance in a device capable of recording this effort in kilograms. Dorsiflexor muscular strength was also measured in kilograms with the maximum effort against an elastic resistance. With the foot stabilized on a mobile platform and a strap secured around the metatarsal heads, participants were instructed to raise the front of the foot keeping the heel resting on the plate (22). The strength of the lower abdominals was evaluated with the aid of a goniometer, used to measure the smallest angle in which volunteers could keep the legs suspended isometrically for 3 seconds (28). The following methods were used to evaluate balance: Four Square Step Test (FSST) (22), Timed Up and Go (TUG) test (22), mediolateral sway range (22), modified balance board (9), Tinetti test (24), and functional reach test (29). Functionality was evaluated through: Timed Up and Go (TUG) test (22), Bath Ankylosing Spondylitis Functional Index (BASFI) (23), GDLAM Protocol (Latin-American Development Group for Maturity) for Assessment of Functional Autonomy 
(24), Oswestry scale $(25,8)$, incapacity sub-scale of the Miami Back Index (25), Roland Morris and Roland Morris Hong Kong questionnaire (27), SF12 (8), and a brief sports functionality questionnaire (8). To evaluate the Quality of Life the following instruments were used: Ankylosing Spondylitis Quality of Life Questionnaire (ASQoL), World Health Organization Quality of Life Questionnaire version for elderly people (WHOQoL-OLD) (24), European Organization for Research and Treatment of Cancer Quality of Life Questionnaire (EORTC QLQ -C30) and the EORTC Questionnaire Specific for Breast Cancer (EORTC QLQ BR23) (26). Muscular resistance and posture were evaluated through: YMCA 1 minute sit-up test (9), leg-lowering test (9), performance of the maximum number of push-ups in accordance with the ACSM protocol of evaluation and grade of postural analysis (9). Fatigue was evaluated using the Brief Fatigue Inventory (BFI) (26). Lumbo-pelvic stability was evaluated with the aid of a biofeedback device. The evaluation of shoulder and trunk biomechanics was performed with the aid of an electronic dynamometer and goniometer system for the evaluation of the passive RoM of the shoulder (28). The participation and adherence to a Pilates exercise program was evaluated through the total number of sessions concluded (30). The studies of Bertolla et al. (21), Bird et al. (22), Altan et al. (23) and Rydeard et al. (27) presented better methodological quality, scoring 8/10 on the PEDro scale. While the studies of Eyigor et al. (26), Emery et al. (28) and Gladwell et al. (8) presented the worst methodological quality, scoring $4 / 10$.

Table 2a - Field studies

\begin{tabular}{|c|c|c|c|c|c|}
\hline Author & $\begin{array}{l}\text { PEDro scale } \\
(\mathrm{n} / 10)\end{array}$ & $\begin{array}{c}\text { Aim/ Sample } \\
\text { ( } \mathrm{n}, \text { gender and age) }\end{array}$ & $\begin{array}{c}\text { Duration and } \\
\text { intervention/ } \\
\text { Variables }\end{array}$ & Results & Bias/ Limitations \\
\hline 20 & $6 / 10$ & $\begin{array}{l}\text { Aim - to verify the } \\
\text { effectiveness of Pilates } \\
\text { on chronic pain in } \\
\text { university student } \\
\text { with nonstructural } \\
\text { scoliosis. } \\
\text { Sample - } 31 \\
\text { university students } \\
\text { with nonstructural } \\
\text { scoliosis, reporting } \\
\text { chronic back pain. }\end{array}$ & $\begin{array}{l}\text { Intervention - } 24 \\
\text { sessions, two times a } \\
\text { week, for } 60 \text { min. } \\
\text { Variables - pain was } \\
\text { measured before and } \\
\text { after } 12 \text { weeks of } \\
\text { treatment with Pilates. }\end{array}$ & $\begin{array}{l}1 \text { - The Pilates led to } \\
\text { a significant decrease } \\
\text { in pain } \\
(P=.0002) \text {. } \\
2 \text { - This did not occur } \\
\text { in the control group } \\
(P=.84) \text {. }\end{array}$ & $\begin{array}{l}\text { - Small sample; } \\
\text { - Control group smaller } \\
\text { than intervention group, } \\
\text { presenting a significant } \\
\text { difference in relation to } \\
\text { the pain; } \\
\text { - No between- } \\
\text { groups evaluation of } \\
\text { significance for other } \\
\text { indicators; } \\
\text { - No blinding. } \\
\text { - Absence of a follow-up } \\
\text { after the termination of } \\
\text { the interventions. }\end{array}$ \\
\hline 21 & $8 / 10$ & $\begin{array}{l}\text { Aim - to verify the } \\
\text { effect of a Pilates } \\
\text { program on flexibility } \\
\text { in young indoor soccer } \\
\text { athletes. } \\
\text { Sample - } 11 \text { athletes } \\
\text { from a youth indoor } \\
\text { soccer team. }\end{array}$ & $\begin{array}{l}\text { Intervention - } 4 \text { weeks } \\
\text { of training, } 3 \text { times per } \\
\text { week, for } 25 \text { minutes. } \\
\text { Variables - flexibility } \\
\text { was evaluated } 24 \\
\text { hours before the } \\
\text { intervention and } 24 \\
\text { hours and } 15 \text { days } \\
\text { after the last session. }\end{array}$ & $\begin{array}{l}\text { 1- The Pilates led to a } \\
\text { significant increase in } \\
\text { both angular and linear } \\
\text { flexibility. }\end{array}$ & $\begin{array}{l}\text { - Small sample; } \\
\text { - No blinding of the } \\
\text { professionals who } \\
\text { administered the } \\
\text { therapy; } \\
\text { - No blinding of the } \\
\text { subjects; } \\
\text { - Short period of } \\
\text { training; } \\
\text { - Short follow-up period } \\
\text { after termination of the } \\
\text { intervention. }\end{array}$ \\
\hline
\end{tabular}


Table 2b - Field studies (continuation)

\begin{tabular}{|c|c|c|c|c|c|}
\hline Author & $\begin{array}{l}\text { PEDro scale } \\
(\mathrm{n} / 10)\end{array}$ & $\begin{array}{c}\text { Aim/ Sample } \\
\text { (n, gender and age) }\end{array}$ & $\begin{array}{c}\text { Duration and } \\
\text { intervention/ } \\
\text { Variables }\end{array}$ & Results & Bias/ Limitations \\
\hline 22 & $8 / 10$ & $\begin{array}{l}\text { Aim - To evaluate } \\
\text { the effects of Pilates } \\
\text { on the balance and } \\
\text { function of elderly } \\
\text { people living in the } \\
\text { community. } \\
\text { Sample - } 32 \text { elderly } \\
\text { people living in the } \\
\text { community were } \\
\text { recruited and } 27 \\
\text { completed the } \\
\text { program. }\end{array}$ & $\begin{array}{l}\text { Intervention - } 5 \text { weeks } \\
\text { of training, } 2 \text { times per } \\
\text { week } \\
\text { Variables - Static and } \\
\text { dynamic balance, as } \\
\text { well as leg strength } \\
\text { were evaluated } \\
\text { before and after the } \\
\text { intervention in the 1st } \\
\text { group, after an interval } \\
\text { of } 6 \text { weeks and after } \\
\text { the intervention in the } \\
2 \text { nd group. }\end{array}$ & $\begin{array}{l}\text { 1- There was no } \\
\text { significant difference } \\
\text { between the control } \\
\text { and Pilates groups. } \\
\mathbf{2} \text { - The Pilates } \\
\text { led to significant } \\
\text { improvements in the } \\
\text { static and dynamic } \\
\text { balance measures. } \\
\mathbf{3} \text { - There was no } \\
\text { significant improvement } \\
\text { in leg strength. } \\
\mathbf{4} \text { - The improvements } \\
\text { caused by the Pilates } \\
\text { had not returned to } \\
\text { baseline levels after } 6 \\
\text { weeks. }\end{array}$ & $\begin{array}{l}\text { - Small sample; } \\
\text { - No blinding of the } \\
\text { professionals who } \\
\text { administered the } \\
\text { therapy; } \\
\text { - No blinding of the } \\
\text { subjects; } \\
\text { - Short training period; } \\
\text { - Absence of a follow-up } \\
\text { after the termination of } \\
\text { the intervention. }\end{array}$ \\
\hline 23 & $8 / 10$ & $\begin{array}{l}\text { Aim - To evaluate } \\
\text { the effects of Pilates } \\
\text { on pain, functional } \\
\text { level and quality } \\
\text { of life in patients } \\
\text { with Ankylosing } \\
\text { Spondylitis. } \\
\text { Sample - 55 } \\
\text { participants, } \\
30 \text { men and } 25 \\
\text { women diagnosed } \\
\text { with Ankylosing } \\
\text { Spondylitis, who were } \\
\text { in regular monitoring } \\
\text { at a Rheumatology } \\
\text { Clinic. }\end{array}$ & $\begin{array}{l}\text { Intervention - Exercise } \\
\text { program of } 1 \text { hour, } 3 \\
\text { times per week, for } 12 \\
\text { weeks. } \\
\text { Variables - Subjects } \\
\text { were evaluated before, } \\
\text { immediately after and } \\
12 \text { weeks after the } \\
\text { treatment regarding: } \\
\text { functional capacity } \\
\text { (BASFI), disease } \\
\text { activity (BASDAI), } \\
\text { spinal mobility } \\
\text { (BASMI), chest } \\
\text { expansion and quality } \\
\text { of life (ASQoL). }\end{array}$ & $\begin{array}{l}1 \text { - The Pilates led to a } \\
\text { significant improvement } \\
\text { in functional capacity } \\
\text { at } 12 \text { and } 24 \text { weeks in } \\
\text { comparison with the } \\
\text { control group. } \\
\mathbf{2} \text { - The Pilates led to a } \\
\text { significant improvement } \\
\text { in BASMI, in BASDAI } \\
\text { and the chest } \\
\text { expansion at week } 12 \text {. } \\
\mathbf{3} \text { - Comparing the } \\
\text { groups, the Pilates } \\
\text { significantly improved } \\
\text { BASDAI (week 12) and } \\
\text { BASMI (week 24). }\end{array}$ & $\begin{array}{l}\text { - Small sample; } \\
\text { - No blinding of the } \\
\text { professionals who } \\
\text { administered the } \\
\text { therapy; } \\
\text { - No blinding of the } \\
\text { subjects; } \\
\text { - Short follow-up period } \\
\text { after termination of the } \\
\text { intervention. }\end{array}$ \\
\hline 9 & $6 / 10$ & $\begin{array}{l}\text { Aim - To determine } \\
\text { the effect of Pilates on } \\
\text { abdominal strength, } \\
\text { hamstring flexibility, } \\
\text { upper body strength, } \\
\text { posture and balance. } \\
\text { Sample - Of the } \\
50 \text { healthy, active } \\
\text { volunteers, aged } \\
\text { between } 25 \text { and } 65 \\
\text { enrolled, } 44 \text { completed } \\
\text { the study. }\end{array}$ & $\begin{array}{l}\text { Intervention - } 1 \text { hour } \\
\text { classes, } 2 \text { times per } \\
\text { week, for } 12 \text { weeks. } \\
\text { Variables - The } \\
\text { following were } \\
\text { evaluated: abdominal } \\
\text { resistance, pelvic } \\
\text { stability, hamstring } \\
\text { flexibility, upper limb } \\
\text { endurance, posture } \\
\text { and balance. }\end{array}$ & $\begin{array}{l}\text { 1- The Pilates } \\
\text { led to significant } \\
\text { improvements in all } \\
\text { the variables except } \\
\text { balance. }\end{array}$ & $\begin{array}{l}\text { - Small sample; } \\
\text { - No blinding; } \\
\text { - Absence of a follow- } \\
\text { up of results after } \\
\text { the termination of the } \\
\text { interventions. }\end{array}$ \\
\hline
\end{tabular}


Table 2c - Field studies (continuation)

\begin{tabular}{|c|c|c|c|c|c|}
\hline Author & $\begin{array}{l}\text { PEDro scale } \\
(\mathrm{n} / 10)\end{array}$ & $\begin{array}{c}\text { Aim/ Sample } \\
\text { (n, gender and age) }\end{array}$ & $\begin{array}{c}\text { Duration and } \\
\text { intervention/ } \\
\text { Variables }\end{array}$ & Results & Bias/ Limitations \\
\hline 24 & $6 / 10$ & $\begin{array}{l}\text { Aim - To evaluate the } \\
\text { effects of Pilates on } \\
\text { personal autonomy, } \\
\text { static balance and } \\
\text { quality of life of healthy } \\
\text { elderly women. } \\
\text { Sample - } 52 \text { elderly } \\
\text { women, sedentary for } \\
\text { at least } 6 \text { months, who } \\
\text { had never participated } \\
\text { in Pilates classes. }\end{array}$ & $\begin{array}{l}\text { Intervention - } \\
\text { Program of } 1 \text { hour, } 2 \\
\text { times a week, for } 8 \\
\text { consecutive weeks. } \\
\text { Variables - GDLAM } \\
\text { Protocol } \\
\text { Evaluation of } \\
\text { Functional Autonomy, } \\
\text { Tinetti test (balance), } \\
\text { WHOQoL-OLD (quality } \\
\text { of life). }\end{array}$ & $\begin{array}{l}\text { 1- The dependent } \\
\text { Student's t-test showed } \\
\text { significant post-test } \\
\text { differences in the areas } \\
\text { of balance and general } \\
\text { index of the GDLAM } \\
\text { protocol; } \\
2 \text { - The Wilcoxon test } \\
\text { showed a significant } \\
\text { post-test difference in } \\
\text { the quality of life index. }\end{array}$ & $\begin{array}{l}\text { - Small sample; } \\
\text { - No blinding; } \\
\text { - Short training period; } \\
\text { - Absence of a follow- } \\
\text { up of results after } \\
\text { the termination of the } \\
\text { interventions. }\end{array}$ \\
\hline 25 & $6 / 10$ & $\begin{array}{l}\text { Aim - To compare the } \\
\text { efficacy of an active } \\
\text { approach (Pilates) with } \\
\text { a passive approach } \\
\text { (massage) to improve } \\
\text { pain and activity } \\
\text { limitations associated } \\
\text { with chronic low } \\
\text { back pain (CLBP) and } \\
\text { recurrent low back } \\
\text { pain (RLBP). } \\
\text { Sample - } 21 \\
\text { volunteers, recruited } \\
\text { from back pain clinics } \\
\text { of Miami and south of } \\
\text { Miami. }\end{array}$ & $\begin{array}{l}\text { Intervention - } 6 \text { weeks } \\
\text { of Pilates or massage } \\
\text { intervention, carried } \\
\text { out } 2 \text { times a week, } \\
\text { with the Pilates lasting } \\
50 \text { minutes and the } \\
\text { massage } 30 \text { minutes. } \\
\text { Variables - Before and } \\
\text { after the intervention, } \\
\text { activity limitation, pain, } \\
\text { physical factors and } \\
\text { psychosocial factors } \\
\text { were evaluated. }\end{array}$ & $\begin{array}{l}\text { 1- There was a } \\
\text { significant improvement } \\
\text { in the Pilates group } \\
\text { compared to the } \\
\text { Massage group for } \\
\text { the trunk extension } \\
\text { strength and vitality } \\
\text { measures of the SF-36. } \\
\text { 2- Both groups showed } \\
\text { improvement in the } \\
\text { majority of the other } \\
\text { outcomes. } \\
\text { 3 - The improvements } \\
\text { were greater for the } \\
\text { subjects receiving } \\
\text { Pilates, except in } \\
\text { functional self-efficacy. }\end{array}$ & $\begin{array}{l}\text { - Small sample; } \\
\text { - No blinding of } \\
\text { the subjects or the } \\
\text { professionals who } \\
\text { administered the } \\
\text { therapy; } \\
\text { - Final evaluation in less } \\
\text { than } 85 \% \text { of the initial } \\
\text { subjects; } \\
\text { - No evaluation of at } \\
\text { least one key outcome } \\
\text { as "intention to treat" } \\
\text { due to non-completion } \\
\text { of the treatment/ } \\
\text { control according to the } \\
\text { distribution; } \\
\text { - Short follow-up period } \\
\text { after termination of the } \\
\text { intervention. }\end{array}$ \\
\hline 26 & $4 / 10$ & $\begin{array}{l}\text { Aim - To evaluate the } \\
\text { impact of Pilates on } \\
\text { physical performance, } \\
\text { flexibility, fatigue, } \\
\text { depression and quality } \\
\text { of life of women } \\
\text { treated for breast } \\
\text { cancer. } \\
\text { Sample - } 60 \text { breast } \\
\text { cancer patients were } \\
\text { pre-selected, } 52 \text { were } \\
\text { included, of these } 42 \\
\text { completed the study. }\end{array}$ & $\begin{array}{l}\text { Intervention - The } \\
\text { I group performed } \\
\text { Pilates exercises for } \\
1 \text { hour, } 3 \text { times per } \\
\text { week, for } 8 \text { weeks. } \\
\text { Variables - The } \\
\text { following were } \\
\text { evaluated before and } \\
\text { after the intervention: } \\
\text { functional capacity } \\
\text { (6-minute walk test), } \\
\text { flexibility (modified } \\
\text { sit and reach test), } \\
\text { fatigue (brief fatigue } \\
\text { inventory), quality } \\
\text { of life (EORTC } \\
\text { QLQ-C30 and EORTC } \\
\text { QLQ BR23) and } \\
\text { complications. }\end{array}$ & $\begin{array}{l}\text { 1- The Pilates group } \\
\text { presented significant } \\
\text { improvements in the } \\
\text { 6-minute walk test and } \\
\text { functional scores of } \\
\text { the EORTC QLQ-C30 } \\
\text { and EORTC QLQ BR23 } \\
\text { questionnaires. } \\
\mathbf{2} \text { - The control group } \\
\text { showed a significant } \\
\text { reduction in the } \\
\text { 6-minute walk test. } \\
\mathbf{3} \text { - In the between- } \\
\text { groups comparison } \\
\text { there was a significant } \\
\text { difference in the } 6 \\
\text { minute walk test in } \\
\text { favor of the Pilates } \\
\text { group. }\end{array}$ & $\begin{array}{l}\text { - Small sample; } \\
\text { - No blinding; } \\
\text { - Short training period; } \\
\text { - Final evaluation in less } \\
\text { than } 85 \% \text { of the initial } \\
\text { subjects; } \\
\text { - No evaluation of at } \\
\text { least one key outcome } \\
\text { as "intention to treat" } \\
\text { due to non-completion } \\
\text { of the treatment/ } \\
\text { control according to the } \\
\text { distribution; } \\
\text { - Short follow-up period } \\
\text { after termination of the } \\
\text { intervention. }\end{array}$ \\
\hline
\end{tabular}


Table 2d - Field studies (continuation)

\begin{tabular}{|c|c|c|c|c|c|}
\hline Author & $\begin{array}{l}\text { PEDro scale } \\
(n / 10)\end{array}$ & $\begin{array}{c}\text { Aim/ Sample } \\
\text { (n, gender and age) }\end{array}$ & $\begin{array}{c}\text { Duration and } \\
\text { intervention/ } \\
\text { Variables }\end{array}$ & Results & Bias/ Limitations \\
\hline 27 & $8 / 10$ & $\begin{array}{l}\text { Aim - To investigate } \\
\text { the efficacy of Pilates, } \\
\text { emphasizing activation } \\
\text { strategies of the } \\
\text { gluteus maximus, } \\
\text { the intensity of } \\
\text { low back pain and } \\
\text { functional disability in } \\
\text { patients with chronic } \\
\text { nonspecific low back } \\
\text { pain. } \\
\text { Sample - } 55 \\
\text { physically active } \\
\text { adults, aged between } \\
20 \text { and } 55 \text { years, living } \\
\text { in Hong Kong were } \\
\text { recruited. Of these, } 39 \\
\text { were included. }\end{array}$ & $\begin{array}{l}\text { Intervention - } 3 \\
\text { sessions of } 1 \text { hour per } \\
\text { week in a specialized } \\
\text { clinic and } 15 \text { minutes } \\
\text { of training at home, } \\
6 \text { times a week for } 4 \\
\text { weeks. } \\
\text { Variables - The } \\
\text { following were } \\
\text { evaluated before and } \\
\text { after the intervention: } \\
\text { pain intensity (NRS- } \\
101 \text { ) and functional } \\
\text { status (Rolland Morris } \\
\text { and RMDQ-HK). } \\
\text { Functional status } \\
\text { was assessed (RMQ/ } \\
\text { RMDQ-HK) oveErro! A } \\
\text { referência de hiperlink } \\
\text { não é válida.r a period } \\
\text { of } 12 \text { months of } \\
\text { monitoring. }\end{array}$ & $\begin{array}{l}1 \text { - There was a } \\
\text { significant reduction in } \\
\text { both pain intensity and } \\
\text { functional disability for } \\
\text { the Pilates group. } \\
2 \text { - There were } \\
\text { significant } \\
\text { improvements in } \\
\text { functional disability } \\
\text { at } 12 \text { months of } \\
\text { monitoring. }\end{array}$ & $\begin{array}{l}\text { - Small sample; } \\
\text { - No blinding of } \\
\text { the subjects or the } \\
\text { professionals who } \\
\text { administered the } \\
\text { therapy; } \\
\text { - Short training period; } \\
\text { - Short follow-up period } \\
\text { after termination of the } \\
\text { intervention. }\end{array}$ \\
\hline 11 & $7 / 10$ & $\begin{array}{l}\text { Aim - To evaluate and } \\
\text { compare the effects } \\
\text { of Pilates exercises on } \\
\text { flexibility and lumbo- } \\
\text { pelvic stability. } \\
\text { Sample - } 40 \text { healthy } \\
\text { volunteers of both } \\
\text { genders, who did not } \\
\text { practice any type of } \\
\text { exercise or sports } \\
\text { activity over } 20 \\
\text { minutes twice a week. }\end{array}$ & $\begin{array}{l}\text { Intervention - The } \\
\text { Pilates group } \\
\text { participated in } \\
45 \text {-minute sessions, } \\
2 \text { times a week for } 8 \\
\text { weeks. } \\
\text { Variables - The } \\
\text { groups were evaluated } \\
\text { at weeks } 0,4 \text { and } 8 \text { of } \\
\text { the study in respect to } \\
\text { flexibility (sit and reach } \\
\text { test) and lumbo-pelvic } \\
\text { stability (biofeedback). }\end{array}$ & $\begin{array}{l}1 \text { - The number of } \\
\text { subjects who passed } \\
\text { the lumbo-pelvic } \\
\text { stability test was } \\
\text { significantly higher in } \\
\text { the Pilates group. } \\
2 \text { - Improved flexibility } \\
\text { in the Pilates group was } \\
\text { significantly higher than } \\
\text { in the control in both } \\
\text { the 4th and in the 8th } \\
\text { week of the training. }\end{array}$ & $\begin{array}{l}\text { - Small sample; } \\
\text { - No blinding of } \\
\text { the subjects or the } \\
\text { professionals who } \\
\text { administered the } \\
\text { therapy; } \\
\text {-Short training period; } \\
\text { - Absence of a follow- } \\
\text { up of results after } \\
\text { the termination of the } \\
\text { interventions. }\end{array}$ \\
\hline 28 & $4 / 10$ & $\begin{array}{l}\text { Aim - To quantify } \\
\text { the effects of a } \\
\text { Pilates program on } \\
\text { shoulder and trunk } \\
\text { biomechanics. } \\
\text { Sample - } 19 \text { healthy } \\
\text { individuals ( } 9 \text { controls } \\
\text { and } 10 \text { of the Pilates } \\
\text { group). }\end{array}$ & $\begin{array}{l}\text { Intervention - } 2 \\
\text { private sessions of } \\
1 \text { hour each, for } 12 \\
\text { weeks. } \\
\text { Variables - The } \\
\text { following were } \\
\text { performed before } \\
\text { and after the } \\
\text { intervention: posture } \\
\text { tests, abdominal } \\
\text { strength, shoulder } \\
\text { RoM, shoulder neck } \\
\text { and torso kinematics, } \\
\text { and the activity of } 16 \\
\text { muscles. }\end{array}$ & $\begin{array}{l}1 \text { - The Pilates group } \\
\text { presented lower static } \\
\text { thoracic kyphosis in } \\
\text { the sitting position } \\
\text { and greater abdominal } \\
\text { strength. } \\
\mathbf{2} \text { - The PG also } \\
\text { showed improved } \\
\text { kinematics during the } \\
\text { shoulder flexion task. }\end{array}$ & $\begin{array}{l}\text { - Small sample; } \\
\text { - Control group differed } \\
\text { from the intervention } \\
\text { group; } \\
\text { - No blinding; } \\
\text { - No evaluation of at } \\
\text { least one key outcome } \\
\text { as "intention to treat" } \\
\text { due to non-completion } \\
\text { of the treatment/ } \\
\text { control according to the } \\
\text { distribution; } \\
\text { - Absence of a follow- } \\
\text { up of results after } \\
\text { the termination of the } \\
\text { interventions. }\end{array}$ \\
\hline
\end{tabular}


Table $2 \mathrm{e}$ - Field studies (continuation)

\begin{tabular}{|c|c|c|c|c|c|}
\hline Author & $\begin{array}{l}\text { PEDro scale } \\
(\mathrm{n} / 10)\end{array}$ & $\begin{array}{c}\text { Aim/ Sample } \\
\text { (n, gender and age) }\end{array}$ & $\begin{array}{c}\text { Duration and } \\
\text { intervention/ } \\
\text { Variables }\end{array}$ & Results & Bias/ Limitations \\
\hline 29 & $6 / 10$ & $\begin{array}{l}\text { Aim - To determine } \\
\text { whether Pilates based } \\
\text { exercises could } \\
\text { improve the dynamic } \\
\text { balance in healthy } \\
\text { adults. } \\
\text { Sample - } 40 \text { healthy } \\
\text { adults who had never } \\
\text { done Pilates were } \\
\text { selected. The results } \\
\text { of } 34 \text { subjects were } \\
\text { analyzed. }\end{array}$ & $\begin{array}{l}\text { Intervention - } 10 \\
\text { Pilates sessions } \\
\text { performed over five } \\
\text { weeks. } \\
\text { Variables - The } \\
\text { functional range test } \\
\text { (FRT) was performed } \\
\text { before and after the } \\
\text { procedure (7 days } \\
\text { after termination). }\end{array}$ & $\begin{array}{l}\text { 1- The Pilates group } \\
\text { presented a significant } \\
\text { improvement in the } \\
\text { post-intervention FRT. } \\
2 \text { - The Control group } \\
\text { presented no significant } \\
\text { change after five } \\
\text { weeks. }\end{array}$ & $\begin{array}{l}\text { - Small sample; } \\
\text { - No blinding of } \\
\text { the subjects or the } \\
\text { professionals who } \\
\text { administered the } \\
\text { therapy; } \\
\text { - No evaluation of at } \\
\text { least one key outcome } \\
\text { as "intention to treat" } \\
\text { due to non-completion } \\
\text { of the treatment/ } \\
\text { control according to the } \\
\text { distribution; } \\
\text { - Short training period; } \\
\text { - Absence of a follow- } \\
\text { up of results after } \\
\text { the termination of the } \\
\text { interventions. }\end{array}$ \\
\hline 8 & $4 / 10$ & $\begin{array}{l}\text { Aim - To evaluate the } \\
\text { effect of a modified } \\
\text { Pilates program for } \\
\text { active individuals with } \\
\text { chronic non-specific } \\
\text { low back pain. } \\
\text { Sample - } 49 \\
\text { individuals with } \\
\text { chronic low back pain } \\
\text { were selected, these } \\
34 \text { completed the } \\
\text { study. }\end{array}$ & $\begin{array}{l}\text { Intervention - } 6 \text { weeks } \\
\text { of Pilates classes, } \\
\text { performed } 1 \text { time per } \\
\text { week for } 1 \text { hour. } 2 \\
\text { sessions of } 30 \text { minutes } \\
\text { were also performed } \\
\text { weekly at home } \\
\text { without supervision. } \\
\text { Variables - The } \\
\text { following were } \\
\text { evaluated before and } \\
\text { after the intervention: } \\
\text { pain (Rolland } \\
\text { Morris visual analog } \\
\text { scale), specific } \\
\text { functional status of } \\
\text { the spine (0swestry } \\
\text { questionnaire), general } \\
\text { functional status } \\
\text { (SF-12), subjective } \\
\text { and sports function } \\
\text { improvement. }\end{array}$ & $\begin{array}{l}\text { 1- In the pre and } \\
\text { post-intervention } \\
\text { comparison, the } \\
\text { Pilates group showed } \\
\text { significant improvement } \\
\text { in general functional } \\
\text { status, sports function, } \\
\text { pain, flexibility and } \\
\text { proprioception. } \\
2 \text { - The mean daily } \\
\text { pain scores decreased } \\
\text { significantly between } \\
\text { the } 1^{\text {st }} \text { and } 6^{\text {th }} \text { week } \\
\text { in the Pilates group } \\
\text { and were significantly } \\
\text { lower than those of the } \\
\text { control group. } \\
3 \text { - In the control group } \\
\text { there was a significant } \\
\text { reduction in the } \\
\text { 0swestry questionnaire } \\
\text { and this reduction was } \\
\text { significantly greater } \\
\text { than that of the Pilates } \\
\text { group. } \\
4 \text { - Increased flexibility } \\
\text { was significantly higher } \\
\text { in the Pilates group, } \\
\text { compared to the Control } \\
\text { group. }\end{array}$ & $\begin{array}{l}\text { - Small sample; } \\
\text { - No blinding of } \\
\text { the subjects or the } \\
\text { professionals who } \\
\text { administered the } \\
\text { therapy; } \\
\text { - Short training period; } \\
\text { - Final evaluation in less } \\
\text { than } 85 \% \text { of the initial } \\
\text { subject; } \\
\text { - No evaluation of at } \\
\text { least one key outcome } \\
\text { as "intention to treat" } \\
\text { due to non-completion } \\
\text { of the treatment/ } \\
\text { control according to the } \\
\text { distribution; } \\
\text { - Absence of a follow- } \\
\text { up of results after } \\
\text { the termination of the } \\
\text { interventions. }\end{array}$ \\
\hline
\end{tabular}


Table $2 \mathrm{f}$ - Field studies (continuation)

\begin{tabular}{|c|c|c|c|c|c|}
\hline Author & $\begin{array}{l}\text { PEDro scale } \\
(\mathrm{n} / 10)\end{array}$ & $\begin{array}{c}\text { Aim/ Sample } \\
\text { (n, gender and age) }\end{array}$ & $\begin{array}{c}\text { Duration and } \\
\text { intervention/ } \\
\text { Variables }\end{array}$ & Results & Bias/ Limitations \\
\hline 30 & $5 / 10$ & $\begin{array}{l}\text { Aim - To measure } \\
\text { the participation } \\
\text { and adherence of } \\
\text { hospitalized elderly } \\
\text { people to a Pilates } \\
\text { exercise program. } \\
\text { Sample - } 39 \text { recently } \\
\text { hospitalized elderly } \\
\text { patients were selected } \\
\text { from a group of } 395 \\
\text { consecutive patients } \\
\text { admitted over a } \\
\text { period of five days of } \\
\text { screening. }\end{array}$ & $\begin{array}{l}\text { Intervention - Pilates } \\
\text { exercises three times } \\
\text { a week with one day } \\
\text { of rest between the } \\
\text { sessions. The subjects } \\
\text { exercised until hospital } \\
\text { discharge or for a } \\
\text { maximum of } 4 \text { weeks } \\
\text { Variables - On } \\
\text { admission the } \\
\text { following were } \\
\text { collected: admission } \\
\text { diagnosis, scores } \\
\text { in the mini-mental } \\
\text { state examination and } \\
\text { maximum resistance } \\
\text { for extension of one } \\
\text { knee. At the end } \\
\text { of the intervention } \\
\text { participation and } \\
\text { adherence were } \\
\text { evaluated, based on } \\
\text { the total number of } \\
\text { sessions completed. }\end{array}$ & $\begin{array}{l}1 \text { - In the exercise } \\
\text { group participation was } \\
71 \% \text { and adherence } \\
63 \% \text {. } \\
\mathbf{2} \text { - In the control group } \\
\text { the participation was } \\
96 \% \text { and adherence } \\
95 \% \text {. } \\
\mathbf{3} \text { - 50\% of the sample } \\
\text { presented cognitive } \\
\text { impairment. } \\
\mathbf{4}-\text { There was no } \\
\text { significant difference } \\
\text { in adherence and } \\
\text { participation among } \\
\text { participants with and } \\
\text { without cognitive } \\
\text { impairment. }\end{array}$ & $\begin{array}{l}\text { - Small sample; } \\
\text { - No blinding of the } \\
\text { evaluators or the } \\
\text { professionals who } \\
\text { administered the } \\
\text { therapy; } \\
\text { - Short training period; } \\
\text { - No evaluation of at } \\
\text { least one key outcome } \\
\text { as "intention to treat" } \\
\text { due to non-completion } \\
\text { of the treatment/ } \\
\text { control according to the } \\
\text { distribution; } \\
\text { - Functionality not } \\
\text { evaluated. }\end{array}$ \\
\hline
\end{tabular}

Note: $\mathrm{BD}=$ Bone densitometry. $\mathrm{HAP}=$ Human Activity Profile questionnaire.

\section{Discussion}

Musculoskeletal disorders are present in a wide variety of health problems. In the studies analyzed, Pilates was used to treat these disorders in patients with Non-structural Scoliosis, Ankylosing Spondylitis, low back pain and breast cancer, as well as for the prevention of injuries in adults, elderly people and athletes.

Scoliosis is a postural change (31) characterized by alterations of the spine in all three planes of movement, with lateral deviation in the frontal plane, lordosis in the sagittal plane and vertebral rotation in the axial plane (32). There are many known causes of scoliosis, which may be congenital or acquired, result from disease or injury as well as from changes in bone structure or neuromuscular problems. However, the majority of cases are of unknown origin and are therefore called idiopathic (33). Recent evidence indicates that physical exercises are able to treat Juvenile Idiopathic Scoliosis, reducing the Cobb angle and producing secondary effects such as improved strength, balance and mobility (34). In relation to the Pilates, despite the positive results indicating improvement in pain and function, the evidence is still limited (35, $36,6)$.

Ankylosing Spondylitis (AS) is a chronic disease characterized by rheumatic inflammation (37) of the axial skeleton and sacroiliac joints (38), which affects men more than women (37). Its main clinical manifestations include back pain and stiffness for more than three months, which improves with exercise, but is not relieved by rest (37). Involvement of peripheral joints is reported in approximately one third of patients, most often in the hip, shoulder and knee (38). Its etiology is unknown and there is still no cure, therefore treatment is aimed at relieving and preventing the symptoms (39). The commonly used therapies consist of the administration of drugs and physical exercise. Physical activity and exercise are increasingly considered an important part of the treatment program (38). Hydrotherapy and exercises based on overall postural reeducation seem to offer a valid and promising alternative for these 
patients (39). Recent studies indicate that Pilates can be promising in the rehabilitation and quality of life of patients with AS, especially for those in the early stages of the disease $(40,41,42)$.

Low back pain with or without pain in the lower limbs is the most common chronic pain disorder, with a significant impact on health, economy and society. It is a multifactorial disorder with many possible causes. Intervertebral discs, joints, ligaments, fasciae, muscles and nerve roots were identified as tissues capable of transmitting low back pain (43). Therapeutic exercise is currently the first-line treatment recommended in clinical guidelines for non-specific chronic low back pain (44). Evidence indicates that Pilates based exercises are superior to minimum interventions for reducing non-specific low back pain, although they are no more effective than other forms of pain reduction exercise (45). Nor are they more efficient than the minimum intervention or other exercises to reduce disability related to chronic low back pain (45).

Breast cancer is the most common cancer among women (46). It is a heterogeneous (47) disease with multiple clinical, pathological and molecular forms (48). The most important risk factors for the disease include gender, age and ethnicity (46). Its incidence and mortality rates generally increase with age, so that women over 45 present greater risk (46). However, in young women it is more often associated with a positive family history and genetic mutations than in older women (49). Current treatment strategies for breast cancer rely on the characterization of the level of protein expression of estrogen and progesterone receptors [estrogen receptor (ER)/ progesterone receptor (PR)], and more recently, the protein expression or gene amplification of human epidermal growth factor (HER2) (48). Breast tumors that cannot express ER/PR and HER2 (triple-negative breast cancer) account for $10 \%$ to $17 \%$ of all breast cancers (48). The experience of each woman with breast cancer is unique, however, they share common perspectives related to the physical and functional side effects of the breast cancer treatment (50). Limitation of activity, reduced range of motion of the upper limbs, lymphedema, fatigue, pain and chemotherapy-induced peripheral neuropathy are well documented concerns of breast cancer survivors (50). Rehabilitation and exercises are effective in preventing and treating many of these side effects (50). Exercises that cover both physical and psychological needs, such as Pilates, have shown beneficial effects, such as improving the quality of life (QoL) and functionality, reducing fatigue and depression. However, research in relation to Pilates is still scarce and involves studies with small samples (51).

Chronological aging, or senescence, is associated with increased risk of chronic diseases, such as cognitive dysfunction, cardiovascular disease, and metabolic syndrome. Due to the extended life expectancy, age-related diseases have increased at an alarming rate in recent decades (52). Frailty is an increasingly recognized geriatric syndrome, in which the individual enters a state of vulnerability caused by the functional reduction of multiple systems (53). Furthermore, it is an independent predictor of mortality, morbidity and institutionalization after surgery (54). Evidence indicates that physical exercise can be used in the treatment of fragility (53) and depression (55), as well as in the prevention of age-related cognitive decline and neurodegenerative diseases (52). The Pilates method appears to have positive effects on neuromotor ability, especially regarding the static and dynamic balance. However, compared to other components of physical fitness (cardiorespiratory endurance, muscle strength, body composition and flexibility), the results are still inconclusive, requiring more studies with high quality methodology $(56,57)$.

All 14 studies showed positive and negative aspects for health, such as: reduction of pain, increased flexibility and improved functional capacity. The effect of Pilates was positive, proving to be efficient to reduce pain, increase flexibility, improve balance, increase abdominal and lower limb strength, and improve spinal mobility, chest expansion and disease activity in patients with ankylosing spondylitis. In addition, it increased the strength of the abdominal muscles and lower limbs, improved lumbo-pelvic stability, posture, proprioception, shoulder kinematics functional autonomy, sports function and quality of life. Regarding balance, there was an improvement that was maintained 6 weeks after intervention (22), however, in the study of Bird et al. (22) there was no significant difference between the control and Pilates groups and in the study of Kloubec (9) there was no significant improvement in balance with Pilates. Despite other studies that found improved functionality with Pilates, in the study by Anderson (25) there was improvement in functionality with massage but not with Pilates and in the study Gladwell et al. (8) the improvement of the Control group was greater 
than the Pilates group. In the study of Mallery et al. (30) the hospitalized elderly patents were able to perform the Pilates program.

\section{Conclusion}

Field studies with samples of various characteristics, which favors the generalization of the data, were analyzed. The studies analyzed indicate that Pilates can be effective both for treating conditions such as scoliosis, low back pain, ankylosing spondylitis and breast cancer, and for the prevention of injuries in adults, elderly people and athletes.

However, due to the high methodological variability, these studies should be viewed with caution. This indicates the need for new studies with high methodological quality and standardization of evaluation instruments.

\section{References}

1. Selby A, Herdman, A. Pilates: Como Criar o Corpo que Você Deseja. São Paulo: Manole; 2000. Portuguese.

2. Anderson BD, Spector AH. Introduction to pilatesbased rehabilitation. Orth Phys Ther Clin. North Am.2000;9(3):395-410.

3. Muscolino JE, Cipriani S. Pilates and the "powerhouse" - I. J Bodyw Mov Ther. 2004;8:15-24.

4. Pilates JH, Miller W. Pilates' Return to Life through Contrology. Boston: Christopher Publishing House; 1945 [cited 2011 Sep 3]. Available from: http://www. hermit.com/hermit/art/control.pdf.

5. Mcneill W. Decision making in Pilates. J Bodyw Mov Ther. 2011;15:103-7.

6. Silva ACLG, Mannrich G. Pilates na reabilitação: uma revisão sistemática. Fisioter Mov. 2009;22(3):p.449-55.

7. Bryan M, Hawson S. The benefits of Pilates exercise in orthopaedic rehabilitation. Tech Orthop. 2003;18(1):126-9.

8. Gladwell V, Head S, Haggar M, Beneke R. Does a program of Pilates improve chronic non-specific low back pain? J Sport Rehabil. 2006;15:338-50.
9. Kloubec JA. Pilates for improvement of muscle endurance, flexibility, balance, and posture. J Strength Cond Res. 2010;24(3):661-7.

10. Hassan EAH, Amin MA. Pilates Exercises Influence on the Serotonin Hormone, Some Physical Variables and the Depression Degree in Battered Women. World J Sport Sci. 2011;5(2):89-100.

11. Phrompaet S, Paungmali A, Pirunsan U, Sitilertpisan P. Effects of Pilates Training on Lumbo-Pelvic Stability and Flexibility. Asian J Sports Med. 2011;2(1):16-22.

12. Bolton, JE, Hurst H.C. Prognostic factors for short-term improvement in acute and persistent musculoskeletal pain consulters in primary care. Chiropr Man Therap. 2011;19(27).

13. Coury, HJCG, Moreira RFC, Dias NB. Efetividade do exercício físico em ambiente ocupacional para controle da dor cervical, lombar e do ombro: uma revisão sistemática. Rev Bras Fisioter. 2009;13(6):461-79.

14. Arab AM, Ghamkhar L, Emami M, Nourbakhsh MR. Altered muscular activation during prone hip extension in women with and without low back pain. Chiropr Man Therap. 2011;19:18.

15. Voet NB, van der Kooi EL, Riphagen II, Lindeman E, van Engelen BG, Geurts ACh. Strength training and aerobic exercise training for muscle disease. Cochrane Database Syst Rev. 2010;(1):CD003907.

16. Warburton DE, Nicol CW, Bredin SS. Health benefits of physical activity: the evidence. CMAJ. 2006;174(6):801-9.

17. Akuthota V, Ferreiro A, Moore T, Fredericson M. Core stability exercise principles. Curr Sports Med Rep. 2008;7(1):39-44.

18. Liberali R. Metodologia Científica Prática: um saberfazer competente da saúde à educação. 2nd ed. Florianópolis (Brazil): Postmix; 2011. 206 p. Portuguese.

19. PEDro - Physiotherapy Evidence Database. Australian: The center for evidence-based physiotherapy. 2012 [cited Feb 25]. Available from: www.pedro.org. $\mathrm{au}$.

20. Araújo MEA, Silva EB, Vieira PC, Cader AS, Mello DB, Dantas EHM. Redução da dor crônica associada à escoliose não estrutural, em universitárias submetidas ao método Pilates. Rev Motriz. 2010;16(4):958-66. 
21. Bertolla F, Baroni BM, Junior ECPL, Oltramari JD. Efeito de um programa de treinamento utilizando o método Pilates ${ }^{\circledR}$ na flexibilidade de atletas juvenis de futsal. Rev Bras Med Esporte. 2007;13(4):222-6.

22. Bird ML, Hill KD, Fell JW. A randomized controlled study investigating static and dynamic balance in older adults after training with Pilates. Arch Phys Med Rehabil. 2012;93(1):43-9.

23. Altan L, Korkmaz N, Dizdar M, Yurtkuran M. Effect of Pilates training on people with ankylosing spondylitis. Rheumatol Int. 2012;32(7):2093-9.

24. Rodrigues BGS, Cader AS, Torres NVOB, Oliveira EM, Dantas EHM. Pilates method in personal autonomy, static balance and quality of life of elderly females. J Bodyw Mov Ther. 2010;14(2):195-202.

25. Anderson BD. Randomized clinical trial comparing active versus passive approaches to the treatment of recurrent and chronic low back pain [dissertation]. Coral Gables: University of Miami; 2005.

26. Eyigor S, Karapolat H, Yesil H, Uslu R, Durmaz B. Effects of Pilates exercises on functional capacity, flexibility, fatigue, depression, and quality of life in female breast cancer patients: a randomized controlled study. Eur J Phys Rehabil Med. 2010;46(4):481-7.

27. Rydeard R, Leger A, Smith D. Pilates-Based Therapeutic Exercise: Effect on Subjects With Nonspecific Chronic Low Back Pain and Functional Disability: A Randomized Controlled Trial. J Orthop Sports Phys Ther. 2006;36(7):472-84.

28. Emery K, De Serres SJ, Mcmillan A, Côté JN. The effects of a Pilates training program on arm-trunk posture and movement. Clin Biomech (Bristol, Avon). 2010;25(2):124-30.

29. Johnson EG, Larsen A, Ozawa H, Wilson CA, Kennedy KL. The effects of Pilates-based exercise on dynamic balance in healthy adults. J Bodyw Mov Ther. 2007;11(3):238-42.

30. Mallery LH, MacDonald EA, Hubley-Kozey CL, Earl ME, Rockwood K, MacKnight C. The Feasibility of performing resistance exercise with acutely ill hospitalized older adults. BMC Geriatr. 2003;3:3.
31. Iunes DH, Cecílio MBB, Dozza MA, Almeida PR. Análise quantitativa do tratamento da escoliose idiopática com o método klapp por meio da biofotogrametria computadorizada. Rev Bras Fisioter. 2010;14(2):13340. Portuguese.

32. Ferreira DMA. Análise da influência do calço e do movimento de inclinação lateral da coluna vertebral em indivíduos com escoliose idiopática [dissertation]. Rio Claro (Brazil): Universidade Estadual Paulista; 2009. 179 p. Portuguese.

33. Kendall FP, Mccreary EK, Provance PE. Músculos: provas e funções. 4th ed. São Paulo: Manole; 1995. p. 119-29. Portuguese.

34. Fusco C, Zaina F, Atanasio S, Romano M, Negrini A, Negrini S. Physical exercises in the treatment of adolescent idiopathic scoliosis: An updated systematic review. Physiother Theory Pract. 2011;27(1):80-114

35. Blum CL. Chiropractic and Pilates Therapy for the Treatment of Adult Scoliosis. J Manipulative Physiol Ther. 2002;25(4):E3.

36. Kim HS. Evidence-Based of Nonoperative Treatment in Adolescent Idiopathic Scoliosis. Asian Spine J. 2014;8(5):695-702.

37. van der Weijden MA, Claushuis TA, Nazari T, Lems WF, Dijkmans BA, van der Horst-Bruinsma IE. High prevalence of low bone mineral density in patients within 10 years of onset of ankylosing spondylitis: a systematic review. Clin Rheumatol. 2012;31(11):1529-35.

38. Dagfinrud H, Halvorsen S, Vøllestad NK, Niedermann K, Kvien TK, Hagen KB. Exercise Programs in Trials for Patients With Ankylosing Spondylitis: Do They Really Have the Potential for Effectiveness? Arthritis Care Res (Hoboken). 2011;63(4):597-603.

39. Ribeiro F, Leite M, Silva F, Sousa O. Exercício Físico no Tratamento da Espondilite Anquilosante: Uma Revisão Sistemática. Órgão Oficial da Sociedade Portuguesa de Reumatologia. Acta Reumatol Port. 2007;(32):129-37.

40. Giannotti E, Trainito S, Arioli G, Rucco V, Masiero S. Effects of physical therapy for the management of patients with ankylosing spondylitis in the biological era. Clin Rheumatol. 2014;33(9):1217-30. 
41. Vieira FT, Faria LM, Wittmann JI, Teixeira W, Nogueira LA. The influence of Pilates method in quality of life of practitioners. J Bodyw Mov Ther. 2013;17(4):483-7.

42. Berea S, Ancuţa C, Miu S, Chirieac R. The Pilates method in ankylosing spondylitis. Revista Română de Reumatologie. 2012;21(2):80-3.

43. Parr AT, Diwan S, Abdi S. Lumbar Interlaminar Epidural Injections in Managing Chronic Low Back and Lower Extremity Pain: A Systematic Review. Pain Physician. 2009;12(1):163-88.

44. Jensen RK, Leboeuf-Yde C, Wedderkopp N, Sorensen JS, Manniche C. Rest versus exercise as treatment for patients with low back pain and Modic changes. A randomized controlled clinical trial. BMC Med. 2012;10:22.

45. Lim EC, Poh RL, Low AY, Wong WP. Effects of PilatesBased Exercises on Pain and Disability in Individuals with Persistent Nonspecific Low Back Pain: A Systematic Review with Meta-analysis. J Orthop Sports Phys Ther. 2011;41(2):70-80.

46. Chopra I, Kamal KM. A systematic review of quality of life instruments in long-term breast cancer survivors. Health Qual Life Outcomes. 2012;10:14.

47. Hynes NE, Dey JH. Potential for targeting the fibroblast growth factor receptors in breast cancer. Cancer Res. 2010;70(13):5199-202.

48. Dolle JM, Daling JR, White E, Brinton LA, Doody DR, Porter PL, et al. Risk Factors for Triple-Negative Breast Cancer in Women Under the Age of 45 Years. Cancer Epidemiol Biomarkers Prev. 2009;18(4):1157-66.

49. Cardoso F, Loibl S, Pagani O, Graziottin A, Panizza P, Martincich L, et al. The European Society of Breast Cancer Specialists recommendations for the management of young women with breast cancer. Eur J Cancer. 2012;48(18):3355-77.

50. Binkley JM, Harris SR, Levangie PK, Pearl M, Guglielmino J, Kraus V, et al. Patient Perspectives on Breast Cancer Treatment Side Effects and the Prospective Surveillance Model for Physical Rehabilitation for Women With Breast Cancer. Cancer. 2012;118(8 Suppl):2207-16.

51. Stan DL, Collins NM, Olsen MM, Croghan I, Pruthi S. The Evolution of Mindfulness-Based Physical Interventions in Breast Cancer Survivors. Evid Based Complement Alternat Med. 2012;2012:758641.
52. Bherer L, Erickson KI, Liu-Ambrose T. A Review of the Effects of Physical Activity and Exercise on Cognitive and Brain Functions in Older Adults. J Aging Res. 2013;2013:657508.

53. Theou O, Stathokostas L, Roland KP, Jakobi JM, Patterson C, Vandervoort AA, et al. The Effectiveness of Exercise Interventions for the Management of Frailty: A Systematic Review. J Aging Res. 2011;2011:569194.

54. Partridge JS, Harari D, Dhesi JK. Frailty in the older surgical patient: a review. Age Ageing. 2012;41(2):142-7.

55. Bridle C, Spanjers K, Patel S, Atherton NM, Lamb SE. Effect of exercise on depression severity in older people: systematic review and meta-analysis of randomised controlled trials. Br J Psychiatry. 2012;201(3):180-5.

56. Cancela JM, Oliveira IM, Rodríguez-Fuentes G. Effects of Pilates method in physical fitness on older adults: A systematic review. Eur Rev Aging Phys Act. 2014;11(2):81-94.

57. Francisco CO, Fagundes AA, Gorges B. Effects of Pilates method in elderly people: Systematic review of randomized controlled trials. J Bodyw Mov Ther. 2015;19(3):500-8.

Received in $10 / 29 / 2013$ Recebido em 29/10/2013

Approved in 09/03/2015 Aprovado em 03/09/2015 